\title{
Emerging options in growth hormone therapy: an update
}

This article was published in the following Dove Press journal:

Drug Design, Development and Therapy

29 August 2011

Number of times this article has been viewed

\section{Stephen F Kemp \\ J Paul Frindik}

University of Arkansas for Medical Sciences, Arkansas Children's Hospital, Little Rock, AR, USA
Correspondence: Stephen F Kemp University of Arkansas for Medical Sciences, Arkansas Children's Hospital I Children's Way, Little Rock, AR 72202-359I, USA

$\mathrm{Tel}+\mid$ 50I $364 \mid 430$

Fax +I 50I 3646299

Email kempstephenf@uams.edu

\begin{abstract}
Growth hormone (GH) was first used to treat a patient in 1958. For the next 25 years it was available only from cadaver sources, which was of concern because of safety considerations and short supply. In 1985, GH produced by recombinant DNA techniques became available, expanding its possible uses. Since that time there have been three indications approved by the US Food and Drug Administration (FDA) for GH-deficiency states and nine indications approved for non-GH-deficiency states. In 2003 the FDA approved GH for use in idiopathic short stature (ISS), which may indirectly cover other diagnoses that have short stature as a feature. However, coverage for GH therapy is usually more reliably obtainable for a specific indication, rather than the ISS indication. Possible future uses for GH therapy could include the treatment of syndromes such as Russell-Silver syndrome or chondrodystrophy. Other non-short-stature indications could include wound healing and burns. Other uses that have been poorly studied include aging and physical performance, in spite of the interest already shown by elite athletes in using GH. The safety profile of GH developed over the past 25 years has shown it to be a very safe hormone with few adverse events associated with it. The challenge for the future is to follow these patients into adulthood to determine whether GH therapy poses any long-term risks.
\end{abstract}

Keywords: growth hormone, somatotropin, anabolic, short stature

\section{Background}

The first report of the use of growth hormone (GH) therapy for GH deficiency (GHD) was in $1958 .{ }^{1}$ Early GH preparations used therapeutically were derived from human cadaver pituitaries. In the USA, human-derived GH was produced and distributed by the National Institute of Health's (NIH) National Pituitary Agency. The preparation was in short supply, resulting in lower than ideal dosing and frequent drug holidays. Potential recipients were required to participate in a research protocol and, to ration the cadaveric $\mathrm{GH}$, the diagnosis of GHD required that the patient have a peak GH level in response to provocative stimuli below a certain level. This requirement gradually increased in response to a better supply of cadaveric $\mathrm{GH}$, starting at $5 \mathrm{ng} / \mathrm{mL}$, then $7 \mathrm{ng} / \mathrm{mL}$, and finally $10 \mathrm{ng} / \mathrm{mL}$ in the early 1980s. In 1985 this preparation was linked to a risk for Creuzfeldt-Jacob disease, ${ }^{2,3}$ and its use was discontinued. In 1979 GH was produced in large quantities by expressing the human GH gene in Escherichia coli. ${ }^{4}$ In 1985, Genentech Inc (San Francisco, CA) was approved by the US Food and Drug Administration (FDA) to market recombinant human $\mathrm{GH}(\mathrm{rhGH}),{ }^{5}$ a product identical to human GH with the addition of a methionine, which was necessary as a start signal for the bacteria to initiate protein synthesis. Use of methionyl GH did result in antibody production, but this was rarely associated with growth attenuation. ${ }^{6}$ Present-day 
commercial preparations all have the identical 191 amino acid sequence of native human pituitary hormone. ${ }^{7}$

Initially GH was injected intramuscularly, but in the mid-1980s (about the time rhGH was introduced), it was shown to be as effective if given as a subcutaneous injection, ${ }^{8}$ which remains the practice today. Early in its use, GH was given twice weekly but this was was increased to three times weekly when the higher frequency was shown to result in an increased growth response. ${ }^{9}$ At about the time of the transition from cadaveric $\mathrm{GH}$ to $\mathrm{rhGH}$, it was demonstrated that daily doses (six or seven injections per week) yielded an even better growth response than the three times per week schedule, ${ }^{10-13}$ and daily administration is commonly used today. It is now clear from data from large databases ${ }^{14-16}$ that GH-deficient children treated with GH are frequently achieving adult heights in the normal adult range, probably as a result of more aggressive dosing, dividing the dose into daily injections, and, perhaps, earlier initiation of treatment.

Since 1985 there have been eight indications for $\mathrm{GH}$ therapy in children approved by the FDA, and an additional indication for increasing the dose during puberty (see Table 1). There have also been three indications for GH use in adults. The basis for these indications has recently been reviewed. ${ }^{17}$

Fifteen years ago, Hintz ${ }^{18}$ reviewed current and potential uses of GH. At that time, GH was already FDA approved in childhood GHD and chronic renal insufficiency, and adult GHD, Turner syndrome, and acquired immune deficiency syndrome (AIDS) wasting were on the brink of FDA approval.

Hintz predicted that other indications that might eventually have FDA approval for treatment of short stature

Table I Approved indications for GH use in the USA and Europe

\begin{tabular}{ll}
\hline Indication & Year of FDA approval \\
\hline GH-deficiency states & \\
Childhood growth-hormone deficiency & $1985(\mathrm{E})$ \\
Adult growth-hormone deficiency & $1996(\mathrm{E})$ \\
Pubertal dosing & 2000 \\
Non-GH-deficiency states & \\
Chronic kidney disease & $1993(\mathrm{E})$ \\
Turner syndrome & $1996(\mathrm{E})$ \\
AIDS wasting & 1996 \\
Prader-Willi syndrome & $2000(\mathrm{E})$ \\
Small for gestational age & 200 I (E) \\
Idiopathic short stature & 2003 \\
Small bowel syndrome & 2004 \\
SHOX deletion & $2006(\mathrm{E})$ \\
Noonan syndrome & 2007 \\
\hline
\end{tabular}

Abbreviations: E, Europe; FDA, US Food and Drug Administration; GH, growth hormone. included what he referred to as "non-growth hormone deficient short stature," which we now call "idiopathic short stature" (ISS), skeletal dysplasia, spina bifida, rickets, Prader-Willi syndrome, and Down syndrome. Of these indications, Prader-Willi syndrome was FDA approved in 2000 and ISS was approved in 2003. The ISS indication has also been approved in Canada and parts of Latin America, although there has not yet been approval in Europe. FDA approval in the USA is limited to non-GHD patients whose height is $>2.25$ standard deviations (SDs) below the mean, who have predicted adult heights that are $>2$ SDs below the mean, who have open epiphyses, and who have no other condition that would better be treated by other means or by observation. There has also been interest in the use of GH as an anabolic agent in situations in which stature is not of paramount importance. Certainly, the anabolic effects of GH are of primary importance in the treatment of adults with GHD, where it has been shown to reduce accumulation of intraabdominal fat, reverse high levels of low-density lipoprotein cholesterol, increase bone mineral density, and reverse some of the symptoms of fatigue. In the treatment of Prader-Willi syndrome, one of the benefits is increase in muscle mass at the expense of fat mass, which serves to improve overall body composition along with improvement in hypotonia, which is a major feature of the syndrome. However, it should be pointed out that FDA approval of treatment of Prader-Willi syndrome was limited to being for the short stature that is a part of the syndrome.

Other possible uses for $\mathrm{GH}$ that $\mathrm{Hintz}^{18}$ mentions include non-islet cell tumor hypoglycemia, fertility, aging, wound healing, cancer cachexia, and amyotrophic lateral sclerosis.

\section{Potential indications for increased height}

FDA approval of the ISS indication in 2003 has allowed $\mathrm{GH}$ to be used for a number of diagnoses that are not GHD. However, it has been difficult to get payers to cover the cost of treating ISS with GH. It is recognized that ISS represents a heterogeneous group of patients who are experiencing growth failure for a variety of reasons, and as more is understood about the etiology of growth failure, many of these patients will have more specific diagnoses. Screening of ISS patients for abnormalities in the SHOX gene has been a logical step. Out of 91 patients with ISS screened, Rao et al reported one patient with a functionally significantly mutation in the SHOX gene. ${ }^{19}$ Ogata expanded the screen to include 400 patients with ISS, and found the aforementioned patient, along with 
three others had SHOX gene mutations. ${ }^{20}$ In an analysis of 68 patients with ISS, one female patient was identified who had a normal karyotype but a deletion of one SHOX allele. ${ }^{21}$

Other genes that have recently been discovered to result in growth failure include defects in the GH receptor's intracellular signaling, in particular STAT5 $b,{ }^{22}$ and a defect in the acid-labile subunit (ALS) of the circulating insulin-like growth factor 1 (IGF-I) complex. ${ }^{23}$ STAT5b deficiency results in a phenotype of GH insensitivity and immunodeficiency, while ALS-deficient patients have rather subtle growth failure with height tracking at about or just below the third percentile. Neither of these defects has been identified in patients diagnosed as having ISS, ${ }^{24,25}$ perhaps in part because they represent very rare disorders. Also, it has been pointed out that the phenotype of STAT5 $b$ deficiency is that of severe GH resistance, and it is not likely to be mistaken for ISS..$^{25}$ Perhaps ALS deficiency has not been identified in a population of ISS patients because the growth failure associated with it is too subtle for the affected child to be labeled as having ISS.

It appears that mutations in the GH receptor and the SHOX gene account for $1 \%-5 \%$ of the cases of growth failure that are designated ISS. As we recognize various causes for ISS, the pool of children with this designation should continue to decrease. ${ }^{26}$

An analysis of patients in a large database ${ }^{27}$ showed that, between 1985 (when rhGH was first used) and 2003, over 8000 patients had been treated for ISS at a time when the database included data from 47,226 total patients. When subgroups of these patients were evaluated for their growth patterns, it was clear that they started GH therapy with very short stature ( -3.2 to $-2.8 \mathrm{SD})$. Except for those who had been in puberty at the start of therapy, patients were followed for 7 years, at which time mean heights were -1 to -1.2 SD.

What have been the repercussions relating to the FDA approval of ISS as an indication for GH treatment? A comparison was made of data in the National Cooperative Growth Study from children who were treated for ISS before 2003 and those treated from 2003 to 2006 (ie, after FDA approval). ${ }^{28}$ Although no major changes were seen, there was a very small decrease in the severity of the growth retardation at entry and a slight increase in the treatment doses. Mean height velocities during treatment were the same before and after FDA approval.

\section{An evaluation of ISS patients}

Since FDA approval of GH treatment for ISS in 2003, there have been several new indications that are for conditions or syndromes in which short stature is part of the condition. To date, these have included the SHOX deletion (including Léri-Weill syndrome $)^{29}$ and Noonan syndrome. Another possible situation in which GH might be used would be for children with skeletal dysplasias. However, a recent study suggests that children with skeletal dysplasias respond poorly to GH therapy.$^{30} \mathrm{~A}$ previous study evaluated 5 years of GH therapy in 35 children with achondroplasia. ${ }^{31}$ Patients were randomized to one of two dosing arms: $0.1 \mathrm{IU} / \mathrm{kg}$ or $0.2 \mathrm{IU} / \mathrm{kg}$. The group receiving the higher dose increased their average height by $0.8 \mathrm{SD}$ during the study; the group receiving the lower dose increased their average height by $0.6 \mathrm{SD}$. They saw no change in body proportions or arm span.

There has also been some interest in treating children with Russell-Silver syndrome with GH. A recent study treated 26 patients with Russell-Silver syndrome to adult height (median treatment time: 9.8 years). ${ }^{32}$ Over this time, the mean height SD of the patients increased from -2.7 to -1.3 . It was also noted that those patients with the shortest height SD at the beginning of GH therapy were the ones that gained the most height with treatment.

\section{Hypophosphatemic rickets}

Hypophosphatemic rickets also includes, autosomal dominant hypophosphatemic rickets, autosomal recessive hypophosphatemic rickets, tumor-induced osteomalacia, and fibrous dysplasia. All of these disorders are characterized by low levels of serum phosphate, which does not allow good function of mature osteoblasts, leading to poor linear growth. X-linked hypophosphatemic rickets (XLHR) is the most common form of hypophosphatemic rickets. Conventional therapy has included supplementation with oral phosphate and vitamin D. Growth response to conventional therapy is disappointing, in part because oral phosphate is unpalatable and there is often noncompliance. Since the advent of recombinant $\mathrm{GH}$, there has been interest in investigating whether $\mathrm{GH}$ would increase the growth response (and ultimately adult height) in patients with this disorder. Due to the rare nature of the disorder, such studies have been limited because of the small numbers of subjects studied. Saggese et al studied twelve subjects, of whom six received conventional therapy plus $\mathrm{GH}$ and six received only conventional therapy. ${ }^{33,34}$ They concluded that those receiving $\mathrm{GH}$ showed an increase in height $\mathrm{Z}$-score, growth velocity $Z$-score, and predicted adult height, along with increases in serum phosphate, bone markers, bone alkaline phosphatase, parathyroid hormone, 1,25-hydroxy vitamin D, and bone mineral density. Reusz et al similarly treated 
six children with XLHR with GH, and showed an increase in height $Z$-score and a slight increase in serum phosphate. ${ }^{35}$ However, there was no control group in this study. Wilson reviewed seven clinical trials and concluded that GH appeared to increase growth velocity, although there were no adult height data. ${ }^{36} \mathrm{He}$ did note that GH therapy appeared to be safe. A subsequent study did report adult height data in a study of treating twelve patients with XLHR (six treated with conventional therapy plus GH, and six treated only with conventional therapy). ${ }^{37}$ These results showed that GH treatment for as long as 10 years was associated with an increase in height SD score of $1 \mathrm{SD}$ at the time adult height was achieved. Another analysis of published data by Huiming and Chaomin found that, of the five published trials they found, only one met their inclusion criteria. ${ }^{38}$ This trial included only five participants, but it did show an increase in height SD score with GH. However, their conclusion was that there was no conclusive evidence that GH therapy in XLHR increased linear growth, changed mineral metabolism, renal function, bone mineral density, or body proportions. However, GH therapy did appear to be safe.

It seems clear, therefore, that treatment with GH is safe for hypophosphatemic rickets, but it is not yet possible to say whether GH treatment is truly effective, or, if there is a growth response, how large an increase in adult height there would be. More investigation with appropriate controls and greater numbers of subjects is necessary before it can be conclusively determined that GH is of benefit in this condition.

\section{Psychological aspects of treating short stature with $\mathrm{GH}$}

It is assumed that short stature is associated with disadvantages and problems of psychological adjustment. Anecdotal reports include teasing, treating children in relation to their height rather than their age (juvenilization), and academic underachievement. ${ }^{39}$ Some studies seem to confirm these notions, ${ }^{40-43}$ while others have failed to demonstrate any disadvantage to short stature, including any problem with psychological adjustment. ${ }^{44-47}$ In fact, Kranzler et al ${ }^{48}$ evaluated 90 children who were sent to a stature clinic and determined that, in fact, they had normal psychological function without externalizing behavior problems, attention problems, or poor social skills, as had been previous reported..$^{42,49,50}$ Sandberg et al reported that juvenilization does occur, but short stature is not associated with any social disadvantage. ${ }^{51}$ Balen et al have suggested that patients referred for ISS seem to be more at risk for psychological problems than those who are not referred. ${ }^{52}$ Further, they indicate that in addition to stature there are other risk factors for psychological difficulty, including: being juvenilized, being male, having low intelligence, having a younger but taller sibling, and being part of a family with low socioeconomic status. In light of this controversy, it is not surprising that it has been difficult to demonstrate that treatment of short stature improves the quality of life of the individual. Many physicians who treat children with ISS believe that by increasing adult height they are improving quality of life ${ }^{53}$ however, there are few objective data to support this notion. ${ }^{54}$ In fact, the idea that short stature is a problem that can be addressed by GH treatment has been recently challenged in the popular press. ${ }^{55}$ Recent reviews of available instruments for evaluating quality of life in children with GHD or ISS suggest that it should be possible to do studies that could help answer whether treatment with GH has a positive or negative effect on quality of life. ${ }^{56,57}$ Chaplin et al have recently published a study on the effect of GH therapy on behavior and psychosocial characteristics in 99 short children treated with GH (32 with GHD and 67 with ISS). ${ }^{58}$ They demonstrated that at baseline these children showed higher levels of internalizing behavior and self-esteem compared with reference values. With GH treatment, behavior measures and depression became closer to the population mean at 3 months. Further, this change was maintained for as long as 24 months. We should expect further studies along this line to know whether GH therapy for short stature is effective beyond merely making children taller. This question is particularly relevant because of the expense of GH therapy - which costs perhaps as much as US\$52,634/inch. ${ }^{59}$ Savage has suggested that for non-GHD short stature, (1) if GH therapy is restricted to a height threshold of -2.5 or $-3.0 \mathrm{SD}$ and, (2) if treatment is limited to those children with slow height velocity, there might be fewer children who would experience a benefit in terms of taller stature that could have been attained without treatment. ${ }^{60}$

As previously discussed, ${ }^{61}$ there are a number of reasons to treat children with ISS, the most important of which is that it does not seem appropriate to withhold treatment from them just because the etiology for their extreme short stature has not yet been discovered. With time there will likely be a larger group of patients in which the etiology of their short stature is elucidated. Other approaches to treating ISS include treating 
with IGF-I (alone or in combination with GH), which has the added risk of adverse events, or delaying puberty, either with LHRH agonists or with an aromatase inhibitor. Both of these approaches are still in experimental stages.

\section{Potential indications, both height-related and anabolic Cystic fibrosis}

Cystic fibrosis (CF) is an autosomal recessive disorder caused by mutation of the CF transmembrane regulator protein, which regulates sodium and chloride transport across epithelial membranes. CF is characterized by viscous secretions of exocrine glands, endocrine pancreas insufficiency, as well as growth failure and malnutrition. Since the advent of recombinant GH there has been interest in using GH to treat the growth issues, as well as to help address some of the nutritional problems relating to their increased energy expenditure. Several studies have suggested that GH therapy in $\mathrm{CF}$ increases growth velocity as well as weight. ${ }^{62,63} \mathrm{~A}$ recent study evaluated ten controlled clinical trials and eight observational studies. In the controlled trials, markers of pulmonary function, anthropometrics, and bone mineralization all appeared to be increased compared with controls. The single-case studies tended to support these findings. With regard to long-term health issues, such as pulmonary exacerbations, hospitalizations, or mortality, the only significant finding was that GH therapy seemed to reduce the rate of hospitalizations. Therefore, data for treatment of $\mathrm{CF}$ appear promising but more studies are necessary to determine whether there are long-term benefits of this treatment.

\section{Potential nonheight-related indications Critically ill patients}

In the $1990 \mathrm{~s}$, there was interest in treating catabolic patients with GH. Two large placebo-controlled studies were undertaken in intensive care patients who had heart or abdominal surgery, trauma, or acute respiratory failure. Both studies were concluded early when an interim evaluation of the data demonstrated that the mortality rate in both studies was significantly higher in those patients receiving $\mathrm{GH}(41.9 \%$ versus $19.3 \%){ }^{64,65}$ It is now recommended not to treat critically ill patients with $\mathrm{GH}$, especially patients with an active infection or sepsis.

\section{Burns}

$\mathrm{GH}$ was used soon after recombinant $\mathrm{GH}$ was available to increase donor site healing in patients with severe burns. ${ }^{66}$
Lal et al demonstrated that patients receiving large doses of $\mathrm{GH}(0.2 \mathrm{mg} / \mathrm{kg} /$ day $)$ had an approximately 14-day decrease in length of stay. ${ }^{67}$ Because of concern about increased mortality seen in critically ill adults, they compared mortality rates between these patients and a control group. Mortality rates for those receiving $\mathrm{GH}$ were not different from controls.

\section{Aging}

It has been noted that there is a decline of about $14 \%$ per decade of age in the levels of both GH and IGF-I. ${ }^{68}$ Because some of the signs of human aging, such as decreased muscle and bone mass, dyslipidemia, and psychological symptoms, are similar to what has been seen with adult GHD, it has been suggested that these signs of aging may be due, at least in part, to the low levels of GH and IGF-I, and has even been given the description “somatopause.” Unfortunately, studies using GH replacement in subjects with somatopause have been somewhat disappointing. ${ }^{69-71}$

\section{Physical performance}

The problem of the use of $\mathrm{GH}$ as a performance enhancer has been well recognized in the world of sports. ${ }^{72}$ It is used for its anabolic and lipolytic properties in an attempt to improve performance and shorten recovery times after injury. In studies with healthy untrained men, addition of $\mathrm{GH}$ to resistance training for 12 weeks failed to increase muscle strength beyond what was gained by training alone. ${ }^{73}$ Further, Yarasheski et al have demonstrated that GH administration does not increase muscle protein synthesis in experienced weight lifters. ${ }^{74}$ However, Birzniece et al have suggested that $\mathrm{GH}$ could affect utilization of metabolic fuels during exercise, leading to enhancement of exercise capacity. ${ }^{72}$ Although GH does increase lean body mass, Birzniece et al suggest that it is likely due to fluid retention, rather than increased muscle mass. ${ }^{72}$ These authors acknowledge that, while GH does not increase muscle strength, power, or aerobic capacity in healthy adults, it does appear to increase anaerobic capacity. While the ability of $\mathrm{GH}$ to increase sprint capacity justifies its ban in sports, it may offer an option of improving physical rehabilitation, as well as physical function and independence in disabled or injured patients.

\section{Safety of GH}

GH adverse events have been carefully documented in a review of GH therapy. ${ }^{75}$ Most adverse events have 
been local-injection-site reactions, which rarely lead to discontinuation. Headache, nausea, and fever have been generally self-limiting and are well tolerated. Adverse events such as edema or carpal tunnel syndrome are seen more often in adults than children, and may be the result of fluid retention caused by $\mathrm{GH} .{ }^{68}$ Adverse events seen particularly in children have included transient idiopathic intracranial hypertension (IIH, also known as pseudotumor cerebri), gynecomastia, and slipped capital femoral epiphysis. ${ }^{76,77}$ The IIH resolved after discontinuation of $\mathrm{GH}$ and restarting at a low dose.

There has been particular interest in evaluating the safety of GH treatment of children with ISS, since these children are often described as "normal short children." Thus, it would be of concern if treating these particular children with $\mathrm{GH}$ put them at any significant risk. Therefore, this group of children has been extensively studied from a safety perspective. An evaluation by Quigley et $\mathrm{al}^{78}$ of safety data from the controlled trial of $\mathrm{GH}$ therapy of children with ISS $^{79}$ and the subsequent dose response study, ${ }^{80}$ as well as an evaluation of $>8000$ ISS patients followed in a large postmarketing database for children treated with $\mathrm{GH},{ }^{27}$ have shown that there are no safety issues in GH therapy different from those seen with treatment of GHD.

There have been concerns about cancer associated with $\mathrm{GH}$ administration. These issues have been recently reviewed. ${ }^{68}$ Acromegaly is known to increase the risk of colorectal cancer. ${ }^{81}$ Epidemiological studies have shown a relationship between tall stature and cancer risk, ${ }^{82}$ between IGF-I levels and the risk of prostate cancer, ${ }^{83}$ and an increase in breast cancer associated with levels of free IGF-I. ${ }^{84}$ One study has suggested that there may be cause for concern because of cases of Hodgkin's disease and colorectal cancer found in long-term follow-up of patients who had received human-derived GH. ${ }^{85}$ Although the incidence of these diseases was greater than the population at large, it was not outside the confidence ranges. Further, follow-up of patients receiving human-derived $\mathrm{GH}$ in the USA has not shown such a correlation. ${ }^{85}$ There has been recent concern from analysis of data in French children who were treated with GH between 1985 and 1996, and then followed until 1996 (the Safety and Appropriateness of Growth hormone treatments in Europe [SAGhE] study). ${ }^{86}$ A retrospective analysis of mortality in this population suggests the possibility of increased cardiovascular disease and bone tumors in adults who received $\mathrm{GH}$ as children. The cardiovascular disease was primarily attributed to subarachnoid or intracerebral hemorrhages. Overall cancer mortality rates were not higher than the general population, but bone tumor-related deaths were five times higher than expected. There appeared to be a dose relationship (risk was highest in patients receiving doses $>50 \mathrm{mcg} /$ day). However, there was no apparent relationship with duration of GH therapy, which would be expected if the increase in mortality was actually related to GH therapy. Data from other European countries should be available over the next several years, and may serve to shed some light on the SAGhE data. A recent report has examined life expectancy in 99 Ecuadorian people with $\mathrm{GH}$ receptor deficiency (GHRD) - that is, who had a defect in their $\mathrm{GH}$ receptor leading to IGF-I deficiency. ${ }^{87}$ The GHRD population had only one cancer (nonfatal), compared with $17 \%$ of the control population. Further, there were no cases of diabetes in the GHRD population, compared with $5 \%$ in the control population. This study provides strong evidence that the GHRD population has resistance to cancer and diabetes.

Overall, GH has been shown to be a safe hormone when used at recommended doses. There are excellent large databases for evaluation of possible safety signals that occur during treatment with $\mathrm{GH}$, such as the National Cooperative Growth Study (NCGS) and the Kabi International Growth Study (KIGS) What is most needed is long-term adult follow-up of those patients who received GH as children.

\section{Conclusion}

From careful studies over the past 25 years, GH appears to be a relatively safe hormone, at least during the time that it is being administered. There are few data relating to long-term follow-up, and this is a challenge for the future. GH is a powerful growth-promoting anabolic hormone, which may have further use in treating a number of short stature conditions, for example Russell-Silver syndrome or chondrodystrophies, as well as X-linked vitamin D-resistant rickets. When used to treat CF it may offer stimulation of linear growth, as well as better energy balance. GH should not be used in critically ill patients, since it has been associated with increased mortality in this population. It may possibly offer benefit in situations of muscle wasting, including aging, and it does appear to offer some advantage in physical performance, which may lead to uses in treating injured patients who could benefit from increased physical function and independence. Further studies are indicated to determine the risks and benefits, as well as the cost relative to the benefits for a number of conditions. 


\section{Disclosure}

The authors report no conflicts of interest in this work.

\section{References}

1. Raben MS. Treatment of a pituitary dwarf with human growth hormone. J Clin Endocrinol Metab. 1958;18(8):901-903.

2. Frasier SD. The not-so-good old days: working with pituitary growth hormone in North America, 1956-1985. J Pediatr. 1997;131(1 Pt 2): S1-S4.

3. Hintz RL. The prismatic case of Creutzfeldt-Jacob disease associated with primary growth hormone treatment. J Clin Endocrinol Metab. 1995;80(8):2298-2301.

4. Goeddel DV, Heyneker HL, Hozumi T, et al. Direct expression in Escherichia coli of a DNA sequence coding for human growth hormone. Nature. 1979;281(5732):544-548.

5. Flodh H. Human growth hormone produced with recombinant DNA technology: development and production. Acta Paediatr Scand Suppl. 1986;325:1-9.

6. Massa GG, Vanderschueren-Lodeweyckx M, Bouillon R. Five-year follow-up of growth hormone antibodies in growth hormone deficient children treated with recombinant human growth hormone. Clin Endocrinol (Oxf). 1993;38(2):137-142.

7. Franklin SL, Geffner ME. Growth hormone: the expansion of available products and indications. Endocrinol Metab Clin North Am. 2009;38(3): 587-611.

8. Wilson DM, Baker B, Hintz RL, Rosenfeld RG. Subcutaneous versus intramuscular growth hormone therapy: growth and acute somatomedin response. Pediatrics 1985;76(3):361-364.

9. Milner RD, Russell-Fraser T, Brook CG, et al. Experience with human growth hormone in Great Britain: the report of the MRC Working Party. Clin Endocrinol (Oxf). 1979;11(1):15-38.

10. Albertsson-Wikland K, Westphal O, Westgren U. Daily subcutaneous administration of human growth hormone in growth hormone deficient children. Acta Paediatr Scand. 1986;75(1):89-97.

11. Jorgensen JO, Moller N, Laruritzen T, Alberti KG, Orskov H, Christiansen JS. Evening versus morning injections of growth hormone $(\mathrm{GH})$ in GH-deficient patients: effects on 24-hour patterns of circulating hormones and metabolites. J Clin Endocrinol Metab. 1990;70(1):207-214.

12. Kastrup KW, Christiansen JS, Andersen JK, Orskov H. Increased growth rate following transfer to daily sc administration from three weekly im injections of hGH in growth hormone deficient children. Acta Endocrinol (Copenh). 1983;104(2):148-152.

13. MacGillivray MH, Baptista J, Johanson A. Outcome of a four-year randomized study of daily versus three times weekly somatropin treatment in prepubertal naive growth hormone-deficient children. Genentech Study Group. J Clin Endocrinol Metab. 1996;81(5): 1806-1809.

14. Blethen SL, Baptista J, Kuntzie J, Foley T, LaFranchi S, Johanson A. Adult height in growth hormone $(\mathrm{GH})$-deficient children treated with biosynthetic GH. The Genentech Growth Study Group. J Clin Endocrinol Metab. 1997;82(2):418-420.

15. Frindik JP, Baptista J. Adult height in growth hormone deficiency: historical perspective and examples from the national cooperative growth study. Pediatrics. 1999;104(4 Pt 2):1000-1004.

16. Maghnie M, Ambrosini L, Cappa M, et al. Adult heights in patients with permanent growth hormone deficiency with and without multiple pituitary hormone deficiencies. J Clin Endocrinol Metab. 2006;91(8): 2900-2905.

17. Richmond EJ, Rogol AD. Current indications for growth hormone therapy for children and adolescents. In: Hindmarsh PC, editor. Current Indications for Growth Hormone Therapy. Vol 18. 2nd ed. Basel: Karger; 2010:92-108.

18. Hintz RL. Current and potential therapeutic uses of growth hormone and insulin-like growth factor I. Endocrinol Metab Clin North Am. 1996;25(3):759-773.
19. Rao E, Weiss B, Fukami M, et al. Pseudoautosomal deletions encompassing a novel homeobox gene cause growth failure in idiopathic short stature and Turner syndrome. Nat Genet. 1997;16(1):54-63.

20. Ogata T. SHOX: pseudoautosomal homeobox containing gene for short stature and dyschondrosteosis. Growth Horm IGF Res. 1999;9 (Suppl B):53-57.

21. Binder G, Schwarze CP, Ranke MB. Identification of short stature caused by SHOX defects and therapeutic effect of recombinant human growth hormone. J Clin Endocrinol Metab. 2000;85(1):245-249.

22. Kofoed EM, Hwa V, Little B, et al. Growth hormone insensitivity associated with a STAT5b mutation. $N$ Engl J Med. 2003;349(12): 1139-1147.

23. Domene HM, Bengolea SV, Martinez AS, et al. Deficiency of the circulating insulin-like growth factor system associated with inactivation of the acid-labile subunit. $N$ Engl J Med. 2004;350(6): $570-577$.

24. Salerno M, Balestrieri B, Matrecano E, et al. Abnormal GH receptor signalling in children with idiopathic short stature. J Clin Endocrinol Metab. 2001;86(8):3882-3888.

25. Savage MO, Camacho-Hübner C, David A, et al. Idiopathic short stature: will genetics influence the choice between GH and IGF-I therapy? Eur J Endocrinol. 2007;157(Suppl 1):S33-S37.

26. Rosenfeld RG. The molecular basis of idiopathic short stature. Growth Horm IGF Res. 2005;15 (Suppl A):S3-S5.

27. Kemp SF, Kuntzie J, Attie KM, et al. Efficacy and safety results of long-term growth hormone treatment of idiopathic short stature. J Clin Endocrinol Metab. 2005;90(9):5247-5253.

28. Kemp SF, Dana K, Frane J, Lippe B. Idiopathic Short Stature (ISS): What has changed since FDA approval of growth hormone $(\mathrm{GH})$ for this diagnosis? Data from the Genentech (GNE) National Cooperative Growth Study (NCGS). Paper presented at the Annual Meeting of The Endocrine Society, June 2-3, 2007; Toronto, Canada.

29. Ross JL, Kowal K, Quigley CA, et al. The phenotype of short stature homeobox gene (SHOX) deficiency in childhood: contrasting children with Leri-Weill dyschondrosteosis and Turner Syndrome. J Pediatr. 2005;147(4):499-507.

30. Bang P, Bjerknes R, Dahlgren J, et al. A comparison of different definitions of growth response in short prepubertal children treated with growth hormone. Horm Res Paediatr. 2011;75(5):335-345.

31. Hertel NT, Eklöf O, Ivarsson S, et al. Growth hormone treatment in 35 prepubertal children with achondroplasia: a five-year dose-response trial. Acta Paediatr. 2005;94(10):1402-1410.

32. Toumba M, Albanese A, Azcona C, Stanhope R. Effect of long-term growth hormone treatment on final height of children with Russell-Silver syndrome. Horm Res Paediatr. 2010;74(3):212-217.

33. Saggese G, Baroncelli GI, Barsanti S. Growth hormone treatment of familial hypophosphatemic rickets. Arch Pediatr. 1998;5(Suppl 4): 360S-363S.

34. Saggese G, Baroncelli GI, Bartellone S, Perri G. Long-term growth hormone treatment in children with renal hypophosphatemic rickets: Effect on growth mineral metabolism, and bone density. $J$ Pediatr. 1995;127(3):395-402.

35. Reusz GS, Miltényi G, Stubnya G, et al. X-linked hypophosphatemia: effects of treatment with recombinant human growth hormone. Pediatr Nephrol. 1997;11(5):573-577.

36. Wilson DM. Growth hormone and hypophosphatemic rickets. J Pediatr Endocrinol Metab. 2000;13(Suppl 2):993-998.

37. Baroncelli GI, Bertelloni S, Ceccarelli C, Saggese G. Effect of growth hormone treatment on final height, phosphate metabolism, and bone mineral density in children with X-linked hypophosphatemic rickets. J Pediatr. 2001;138(2):236-243.

38. Huiming Y, Chaomin W. Recombinant growth hormone therapy for $\mathrm{X}$-linked hypophosphatemia in children. Cochrane Database Syst Rev. 2005; Jan 25(1):CD004447.

39. Ross JL, Sandberg DE, Rose SR, et al. Psychological adaptation in children with idiopathic short stature treated with growth hormone or placebo. J Clin Endocrinol Metab. 2004;89(10):4873-4878. 
40. Gordon M, Crouthamel C, Post EM, Richman RA. Psychological aspects of constitutional short stature: social competence, behavior problems, self-esteem, and family functioning. J Pediatr. 1982;101(3): 477-480.

41. Siegal PT, Clopper RR, Stabler B. Psychological impact of significantly short stature. Acta Paediatr Scand Suppl. 1991;377:14-18.

42. Stabler B, Clopper RR, Siegal PT, Stoppani C, Compton PG, Underwood LE. Academic achievement and psychological adjustment in short children: the national cooperative growth study. J Dev Behav Pediatr. 1994;15(1):1-6.

43. Steinhausen HC, Dorr HG, Kannenberg R, Malin Z. The behavior profile of children and adolescents with short stature. J Dev Behav Pediatr. 2000;21(6):423-428.

44. Downie AB, Mulligan J, Stratford RJ, Betts PR, Voss LD. Are short normal children at a disadvantage? The Wessex growth study. BMJ. 1997;314(7074):97-100.

45. Skuse D, Gilmour J, Tian CS, Hindmarsh PC. Psychological assessment of children with short stature: a preliminary report. Acta Paediatr Suppl. 1994;406:11-16.

46. Voss LD. Short normal stature and psychological disadvantage: a critical review of the evidence. J Pediatr Endocrinol Metab. 2001; 14(6):701-711.

47. Voss LD, Bailey BJ, Mulligan J, Wilkin TJ, Betts PR. Short stature and school performance - the Wessex growth study. Acta Paediatr Scand Suppl. 1991;377:29-31.

48. Kranzler JH, Rosenbloom AL, Proctor B, Diamond FB. Is short stature a handicap? A comparison of the psychosocial functioning of referred and nonreferred children with normal short stature and children with normal stature. J Pediatr. 2000;136(1):96-102.

49. Stabler B. Growth hormone insufficiency during childhood has implications for later life. Acta Paediatr Scand Suppl. 1991;377: 9-13.

50. Underwood LE. The social cost of being short: societal perceptions and biases. Acta Paediatr Scand Suppl. 1991;377:3-8.

51. Sandberg DE, Bukowski WM, Fung CM, Noll RB. Height and social adjustment: are extremes a cause for concern and action? Pediatrics. 2004;114(3):744-750.

52. Visser-van Balen H, Sinnema G, Geenen R. Growing up with idiopathic short stature: psychosocial development and hormone treatment: a critical review. Arch Dis Child. 2006;91(5):433-439.

53. Kemp SF. Height and social adjustment. Pediatrics. 2005;115(2): 515-516.

54. Cohen P, Rogol AD, Deal CL, et al. Consensus statement on the diagnosis and treatment of children with idiopathic short stature: a summary of the Growth Hormone Research Society, the Lawson Wilkins Pediatric Endocrine Society, and the European Society for Paediatric Endocrinology workshop. J Clin Endocrinol Metab. 2008; 93(11):4210-4217.

55. Cosgrove C, Cohen S. Normal at Any Cost: Tall Girls, Short Boys, and the Medical Industry's Quest to Manipulate Height. New York, NY: Penguin Group; 2009.

56. Brutt AL, Sandberg DE, Chaplin J, et al. Assessment of health-related quality of life and patient satisfaction in children and adolescents with growth hormone deficiency or idiopathic short stature - Part 1: a critical evaluation of available tools. Horm Res. 2009;72(2):65-73.

57. Bullinger M, Koltowska-Haggstrom M, Sandberg DE, et al. Healthrelated quality of life of children and adolescents with growth hormone deficiency or idiopathic short stature-Part 2: available results and future directions. Horm Res. 2009;72(2):74-81.

58. Chaplin JE, Kriström B, Jonsson B, et al. Improvements in behaviour and self-esteem following growth hormone treatment in short prepubertal children. Horm Res Paediatr. 2011;75(4):291-303.

59. Lee JM, Davis MM, Clark SJ, Hofer TP, Kemper AR. Estimated costeffectiveness of growth hormone therapy for idiopathic short stature. Arch Pediatr Adolesc Med. 2006;160(3):263-269.

60. Savage MO. Should idiopathic short stature be treated with growth hormone? Nat Clin Pract Endocrinol Metab. 2009;5(3):148-149.
61. Frindik JP, Kemp SF. Managing idiopathic short stature: role of somatropin (rDNA origin) for injection. Biologics. 2010;4:147-155.

62. Hardin DS, Ellis K, Dyson M, McConnel R, Rice J, Seilheimer DK. Growth hormone improves clinical status in children with cystic fibrosis: results of a randomized controlled trial. J Pediatr. 2001;139(5): 636-642.

63. Hardin DS, Rice J, Ahn C, et al. Growth hormone treatment enhances nutrition and growth in children with cystic fibrosis receiving enteral nutrition. J Pediatr. 2005;146(3):324-328.

64. Ruokonen E, Takala J. Dangers of growth hormone therapy in critically ill patients. Curr Opin Clin Nutr Metab Care. 2002;5(2):199-209.

65. Takala J, Ruokonen E, Webster NR, et al. Increased mortality associated with growth hormone treatment in critically ill adults. $N$ Engl J Med. 1999;341(11):785-792.

66. Herndon DN, Barrow RE, Kunkel KR, Broemeling L, Rutan RL. Effects of recombinant human growth hormone on donor-site healing in severely burned children. Ann Surg. 1990;212(4):424-429.

67. Lal SO, Wolf SE, Herndon DN. Growth hormone, burns and tissue healing. Growth Horm IGF Res. 2000; (SupplB 10):S39-S43.

68. Cummings DE, Merriam GR. Growth hormone therapy in adults. Annu Rev Med. 2003;54:513-533.

69. Lanfranco F, Gianotti L, Giordano R, Pellegrino M, Maccario M, Arvat E. Ageing, growth hormone and physical performance. $J$ Endocrinol Invest. 2003;26(9):861-872.

70. Sattler FR, Bhasin S, He J, et al. Durability of the effects of testosterone and growth hormone supplementation in older community dwelling men: The HORMA trial. Clin Endocrinol (Oxf). Mar 4, 2011. doi: 10.1111/j.1365-2265.2011.04014.x.

71. Savine R, Sönksen PH. Is the somatopause an indication for growth hormone replacement? J Endocrinol Invest. 1999;22(Suppl 5):142-149.

72. Birzniece V, Nelson AE, Ho KKY. Growth hormone and physical performance. Trends Endocrinol Metab. 2011;22(5):171-178.

73. Yarasheski KE, Campbell JA, Smith K, Rennie MJ, Holloszy JO, Bier DM. Effect of growth hormone and resistance exercise on muscle growth in young men. Am J Physiol. 1992;262(3 Pt 1):E261-267.

74. Yarasheski KE, Zachweija JJ, Angelopoulos TJ, Bier DM. Short-term growth hormone treatment does not increase muscle protein synthesis in experienced weight lifters. J Appl Physiol. 1993;74(6):3073-3076.

75. Krysiak R, Gdula-Dymek A, Bednarska-Czerwińska A, Okopień B. Growth hormone therapy in children and adults. Pharmacol Rep. 2007; 59(5):500-516.

76. Festen DA, van Toorenenbergen A, Duivenvoorden HJ, HokkenKoelega AC. Adiponectin level in prepubertal children with PraderWilli syndrome before and after growth hormone therapy. J Clin Endocrinol Metab. 2007;92(4):1549-1554.

77. Root AW, Root MJ. Clinical pharmacology of human growth hormone and its secretagogues. Curr Drug Targets Immune Endocr Metabol Disord. 2002;2(1):27-52.

78. Quigley CA, Gill AM, Crowe BJ, et al. Safety of growth hormone treatment in pediatric patients with idiopathic short stature. J Clin Endocrinol Metab. 2005;90(9):5188-5196.

79. Leschek EW, Rose SR, Yanovski JA, et al. Effect of growth hormone treatment on adult height in peripubertal children with idiopathic short stature: a randomized, double-blind, placebo-controlled trial. J Clin Endocrinol Metab. 2004;89(7):3140-3148.

80. Wit JM, Rekers-Mombarg LTM, Cutler GB Jr, et al. Growth hormone $(\mathrm{GH})$ treatment to final height in children with idiopathic short stature: evidence for a dose effect. J Pediatr. 2005;146(1):45-53.

81. Renehan AG, Brennan BM. Acromegaly, growth hormone and cancer risk. Best Pract Res Clin Endocrinol Metab. 2008;22(4):639-657.

82. Gunnell D, Okasha M, Smith GD, Oliver SE, Sandju J, Holly JM. Height, leg length, and cancer risk: a systematic review. Epidemiol Rev. 2008;23(2):313-342.

83. Rowlands MA, Gunnell D, Harris R, J. VL, Holly JM, Martin RM. Circulating insulin-like growth factor peptides and prostate cancer risk: a systematic review adn meta-analysis. Int J Cancer. 2009;124(10): 2416-2429. 
84. Peyrat JP, Bonneterre J, Hecquet B, et al. Plasma insulin-like growth factor-1 (IGF-1) concentrations in human breast cancer. Eur J Cancer. 1993;29A(4):492-497.

85. Swerdlow AJ, Higgins CD, Adlard P, Preece MA. Risk of cancer in patients treated with human pituitary growth hormone in the UK, 1959-85: a cohort study. Lancet. 2002;360(9329):273-277.

86. Carel JC, Butler G. Safety of recombinant human growth hormone. Endocr Dev. 2010;18:40-54.
87. Guevara-Aguirre J, Balasubramanian P, Guevara-Aguirre M, et al. Growth hormone receptor deficiency is associated with a major reduction in pro-aging signaling, cancer, and diabetes in humans. Sci Transl Med. 2011;3(70):70ra13.

\section{Publish your work in this journal}

Drug Design, Development and Therapy is an international, peerreviewed open-access journal that spans the spectrum of drug design and development through to clinical applications. Clinical outcomes, patient safety, and programs for the development and effective, safe, and sustained use of medicines are a feature of the journal, which has also been accepted for indexing on PubMed Central. The manuscript management system is completely online and includes a very quick and fair peer-review system, which is all easy to use. Visit http://www.dovepress.com/testimonials.php to read real quotes from published authors.

Submit your manuscript here: http://www.dovepress.com/drug-design-development-and-therapy-journal 